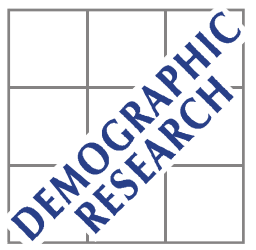

Demographic Research a free, expedited, online journal

of peer-reviewed research and commentary in the population sciences published by the Max Planck Institute for Demographic Research

Konrad-Zuse Str. 1, D-18057 Rostock · GERMANY

www.demographic-research.org

DEMOGRAPHIC RESEARCH

VOLUME 15, ARTICLE 19, PAGES 517-536

PUBLISHED 08 DECEMBER 2006

http://www.demographic-research.org/Volumes/Vol15/19/

DOI: $10.4054 /$ DemRes.2006.15.19

Research Article

Progression to third birth in Morocco in the context of fertility transition

Agata V. D’Addato

(C) 2006 D’Addato

This open-access work is published under the terms of the Creative Commons Attribution NonCommercial License 2.0 Germany, which permits use, reproduction \& distribution in any medium for non-commercial purposes, provided the original author(s) and source are given credit.

See http:// creativecommons.org/licenses/by-nc/2.0/de/ 


\section{Table of Contents}

1 Introduction $\quad 518$

$2 \quad$ Theoretical background and research hypotheses 518

3 Preliminary findings and model specification $\quad 524$

4 Results $\quad 528$

$\begin{array}{lll}5 & \text { Conclusions } & 531\end{array}$

6 Acknowledgements $\quad 532$

References 533 


\title{
Progression to third birth in Morocco in the context of fertility transition
}

\author{
Agata V. D'Addato ${ }^{1}$
}

\begin{abstract}
Progression from second to third birth is a critical reproductive decision in contemporary Morocco. The study thus aims at analyzing the main determinants of third-birth intensities, applying an event-history analysis to the most recent Moroccan survey data. Differences among social groups still persist in the country. Nevertheless, in the background of current modernization and geared to promote women's status, all segments of the population are rapidly changing their fertility behavior. This applies even to the most laggard group, such as illiterate women. The analysis also shows no significant or clear evidence of sex preference among Moroccan mothers in the progression to the third child.
\end{abstract}

\footnotetext{
${ }^{1}$ Institut National d'Études Démographiques fellow (Paris). European Doctoral School of Demography at the Max Planck Institute for Demographic Research (Rostock). E-mail: daddato@demogr.mpg.de.
} 


\section{Introduction}

The fertility patterns of the Southern and Eastern Mediterranean shores are very different from those of the lowest-low fertility countries of the Northern shore. However, recently fertility decline has been spreading rapidly in the former region, especially in the Maghreb (Di Comite and Moretti 1999, Héran 2004, Tabutin and Schoumaker 2005).

This paper focuses on Morocco, which today is characterized by falling fertility levels and by important changes in the intermediate determinants of fertility. In general, if the first phase of fertility transition is marked by an increase in the mean age at marriage, in the long term a diffusion tendency towards smaller families plays an even greater role for countries witnessing advanced transition, such as contemporary Morocco. The progression from second to third birth thus is a crucial component in reproductive change, since the reduction especially of third and higher-order births maintains fertility decline (Yavuz 2005).

For these reasons, the study aims at analyzing the main determinants of the thirdbirth intensities of two-child mothers in Morocco, applying an event-history analysis to the most recent retrospective survey data.

Section 2 provides some key aspects of fertility transition in Morocco and states the research hypotheses. Section 3 specifies the data and methods used, and describes some preliminary descriptive findings. The results are discussed in Section 4, followed by a summary and conclusions of the analysis in the final section.

\section{Theoretical background and research hypotheses}

Morocco of today is experiencing a dynamic process of modernization, affecting a variety of issues, such as fertility and nuptial behavior, family planning, contraceptive use, the familial role and social status of women, and political orientations, thus posing a challenge to the very foundations of the patriarchal system (Salvini 1994, Fargues 1995, 2003a).

Until the Sixties, Morocco has witnessed a typically pre-transitional demographic regime, characterized by very high fertility and mortality levels. In the following decades, the social, economic, and political evolution of the country as well as the consequent impact on people's mentalities and attitudes towards procreation determined deep demographic changes at each level. Morocco was close to natural fertility in the Sixties: a Moroccan woman had 6.96 children on average (CERED 1997, 1998). The period fertility rate rose in the early Seventies, peaking at 7.40, only to decline continually since the mid-1970s (Figure 1). 
On the basis of some indirect determinants of fertility ${ }^{2}$, one would have assumed that Morocco was at a disadvantage in terms of fertility decline (Yaakoubd 1997). And yet, fertility transition in Morocco has been fast and sustained, although the way was paved by no decisive breakthrough or epidemiologic revolution. The converse holds for other Arab countries - Egypt, Syria, and the Gulf States - where fertility remained stubbornly high despite declining infant mortality, rising enrolment into education, decreasing illiteracy, rising incomes and consumption, etc. The onset of Moroccan fertility transition in 1975 was marked by a political and economic turning point; within a few years, the state lost one of its key sources of non-tax revenues: phosphate (Courbage 1995, Rashad and Khadr 2002). Half the value was wiped off prices within a few months and this at a time when war in the Sahara was making large demands on military spending. The fertility rate plunged in four years, from 7.40 in 1973 to 5.90 in 1977, representing a massive drop of 5.5\% a year. Faced with falling land resource revenues, the state turned to its citizens: individual taxes as well as total tax rose by more than 50\% between 1972 and 1975 . Moroccan families instantly faced an unprecedented situation in that most educational, social, health, and military expenditures were now based on their own personal budgets rather than on the windfall profits of the state. Thus, the new role of government was no longer that of a giver but that of a taker of incomes, driving a renewed imperative: family self-reliance (Deane Abernethy 2002). Female economic activity became a major determinant of falling fertility in 1975, when the economic crisis pushed women into the labor market. Having traditionally regarded women's place to be in the home, the state now encouraged female participation in the economy. As a result, the rate of female labor-market participation began to climb and female labor began to replace mineral wealth revenues. The new pace of life, increasing time pressure, and the weakening of family networks, which formerly provided childcare and child rearing, largely affected marriage and reproductive decisions. The opportunity costs of birth became a factor to consider in adapting family strategies even among illiterate groups.

The Eighties were the final trigger that was associated with a change in reproductive behavior in Morocco. Delayed marriage, increasing knowledge of and access to contraceptives as well as radical socio-economic changes in the country, such as rising female educational attainment, strong urbanization, and migration abroad, all combined lead to a sharp decline in Moroccan fertility; according to the Demographic and Health Survey (DHS) of 2003/04, fertility fell to 5.52 in 1982, 4.46 in 1988, 3.28 in 1994, 2.80 in 1999, and more recently, 2.50. In terms of fertility transition, the decline has not been uniform across the country as different sections of the population have

\footnotetext{
${ }^{2}$ For instance, land, economic indicators, the standard of living, the distribution of wealth, infant and child mortality, overall and female education, gender inequity, and child labor.
} 
been affected by social and cultural changes in different ways and at varying pace. Urban and rural fertility indicate that some parts of the population are already rapidly nearing below-replacement fertility: according to the last DHS, the TFR stood at 2.10 in urban areas and at 3.00 in rural settings (Figure 1).

Figure 1: Total fertility rate by place of residence in Morocco, 1973-2003.

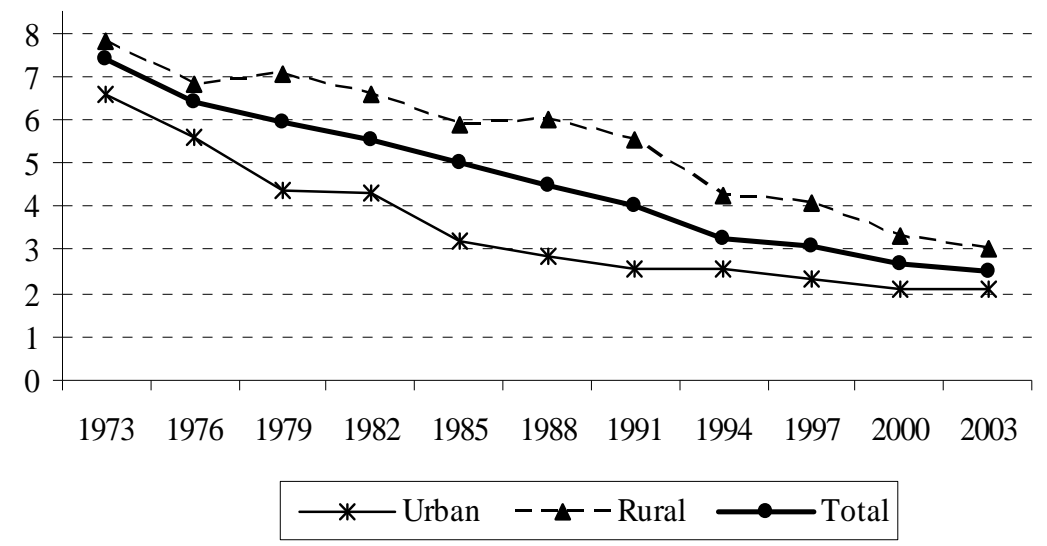

Source: own calculations based on data from the Moroccan Statistical Office, various years.

As the literature well documents, the proximate determinants of fertility transition are relatively clear: marriage postponement followed by spreading contraception. Because in most developing countries in general, and in Morocco in particular, childbearing takes place within the context of conjugal union and nuptiality patterns are closely linked to fertility patterns, marriage and childbearing are viewed as interrelated social and demographic events, and as sequential phases in the life cycle of women. A higher female age at marriage and later family formation thus are factors that have significantly contributed to depress fertility; a higher median age at marriage reduces the average interval of procreation because of the contraction of the exposure period to childbearing. In particular, the average age of women at first marriage, 18.8 in 1992, rose to 21.4 in 2003/04 according to the Moroccan DHS of 1992 and the last DHS of 2003/04, respectively (Azelmat, Ayad, and Abdelmoneim 2005). Rising contraceptive use, together with postponed marriage, represents the other main proximate cause of falling fertility. However, in Morocco the relative proportion of the two factors nuptiality and contraception - has varied over time and space (Ajbilou 1998, Bakass 2003). Between 1960 and 1971, the mean age at marriage of only 17.3 years witnessed an increase, but there was no decline in the total fertility rate. Between 1971 and 1982, the rising mean age at marriage instigated a fall in the total fertility rate from over 7 
children to 5.52; this is not the only contributing factor to declining fertility, however. Nuptiality was responsible for a $1.45 \%$ drop in the average annual reduction of $2.40 \%$. Other factors - contraception foremost among them - made a not insignificant contribution of $0.95 \%$. From 1982 to 1987, fertility decline accelerated by $4.20 \%$ per annum, mainly caused by a rise in the mean age at marriage (by 2.60\%) rather than by contraception (by 1.60\%). However, the annual fertility drop of $4.42 \%$ between 1987 and 1994 is attributable to declining marital fertility (by 3.62\%) rather than to a rise in the mean age at marriage (by $0.70 \%$ per annum) (Courbage 1999a). Government action aimed at lowering fertility has contributed to the diffusion of contraceptive methods in Morocco and to an improvement in the social status of women. It is generally argued that family planning programs are successful only if they jointly act with important socio-economic changes, promoting women's status and arousing the desire to limit the size of the family (Mason 1985). The 1960s marked the turning point in Moroccan population policy: it became less pronatalist in nature and family planning programs were initiated (Eltigani 2001). Nevertheless, Moroccan family planning policy is not very explicit on this front: although family planning methods are available in government health facilities, the government has not enacted legal reforms to facilitate the adoption of modern family planning methods. Generally, while the Moroccan government expresses the desire to reduce population growth, a concerted effort to set targets and mobilize government resources to increase the practice of family planning is lacking. Thus, although family planning is available to many segments of the Moroccan population, it is not easily accessible (Makhlouf Obermeyer 1993).

The rapid fertility decline in Morocco has also been prominently driven by socioeconomic and cultural forces; the role they play is influenced by idea diffusion, social interaction, and development (Bongaarts 2006). Increasing educational standards are traditionally considered an essential determinant of changes in women's reproductive choices: women who have a higher level of schooling are more likely to delay marriage and childbearing, their children tend to be healthier and their participation in the labor force is higher. Therefore, it is generally claimed that female education represents the keystone to the transition from a traditional fertility regime to a modern one. Until the mid-1970s, the commonly held view was that fertility falls uniformly with education. This view was consonant with the classic model of demographic transition, hypothesizing that steady fertility decline runs in parallel with socio-economic development. Education, then, seems to remove the divergences in fertility among different countries; such differences continue to be high only for illiterate women, they are still perceived for women with a low to medium level of education, and they are negligible as to the better educated (Fargues 1988). However, an extensive review of the available empirical evidence up to the late 1970s casts doubts on these long-held assumptions (Cochrane 1979). The expected inverse association was not found in many 
poor, mostly illiterate, rural societies. Instead, an inverted U-shaped relationship was documented in several developing countries. As it has clearly been underlined by Courbage (1994a, 1994b, 1994c, 1999b), the relationship between education and fertility appears to be subject to change, depending on the countries and, especially in the Mediterranean macro region, it sometimes reveals deep ambiguities. In general, it can be argued that the impact of individual schooling on reproductive behavior varies over countries, depending on their stage of fertility transition: the effect seems to be weak mostly in illiterate societies, it gains in strength as societies improve their overall education and make transitional advances - such as in contemporary Morocco - and it falls in prominence again in societies that have just passed the fertility transition and once a relatively low level of fertility has been reached. Moroccan reproductive behavior is also changing as the result of strong urbanization in the country, a process from which emanates the preference towards smaller families. From a demographic viewpoint, urbanization implies the concentration of the population in urban areas, taking a sociological point of view, it implies the diffusion of "urban behaviors", characterized by individualism, isolation, anonymity, and competition, all of which are features that lead to a reduction in family size and to a weaker patriarchal system. The indirect effect of international migration on the mentality of non-migrants and on the whole society of origin may also have played an important role in the inception and rapid spread of transition in Morocco as well as in the diffusion of low fertility. Openness to the outside world, and notably to extranational living models and customs through international migration, may have influenced reproductive behavior in the country of origin, owing to relationships with emigrants and the mass media. As Courbage puts it, "La migration internationale, ses apports en capitaux, génère une intensification agricole qui incite au calcul économique plus sophistiqué et à des stratégies familiales adaptées: moins d'enfants mais mieux formés, par exemple. De surcroît, par un effet de mimétisme, la migration internationale a des effets en boule de neige. Les familles de non-migrants, doivent, pour ne pas perdre leur statut social, trouver des alternatives viables et évoluer." (2001, page 474).

Therefore, substantial developmental changes have occurred over the last decades in Morocco owing to many factors that are generally believed to be conducive to fertility decline and to influence reproductive outcomes. All of these factors have contributed to push the issue of women's emancipation from their traditional role of wives and mothers to enhance their position within the family authority structure, and to promote the development of decisional autonomy, playing a major role in shaping fertility behavior. However, even though unequivocal signs confirm that a multidimensional process of modernization is taking place in Morocco, this process seems to show different patterns across the country in terms of speed and it appears to 
be determined by the stratifications still persisting in the population, specifically in terms of economic well-being, education, residence, and the gender system.

Thus, the author would like to see through an analysis of current individual data whether or not Morocco has "pioneer" subgroups that have a stronger propensity to restrict their family size, e.g. higher educated women or women who have been brought up in an urban context.

On the basis of the literature, the status of women is expected to impact their reproductive behavior, causing differentiated risks of third birth. The author is specifically interested in verifying the hypothesis that postponement of marriage, spacing of births, rising educational standards, and an urban background lead to a higher propensity to establish smaller families. In addition, according to previous studies couples in many countries express a decided preference for children of a particular sex and their preference is attributable to a variety of social, economic, and cultural factors (Cain 1984, Makhlouf Obermeyer 1996, 1999). A strong preference for children of a particular sex may be a significant obstacle to fertility decline if couples who have already reached their desired family size continued childbearing to try for a child of the preferred sex (Da Vanzo and Starbird 1991). Preference towards a son is prevalent in many regions of the world, but the preference for a balanced number of daughters and sons is also common; even where the son preference is strong, couples usually express a desire to have at least one child of each sex (Repetto 1972, Makhlouf Obermeyer and Cardenas 1997). For example, analyzing Demographic and Health Surveys from 26 countries, Arnold (1992) reports that the most common pattern of sexpreference is for at least one son and one daughter. Contraceptive use in a number of countries also shows preference for a balanced number of sons and daughters, often along with a moderate son preference (for example, in Kenya, Morocco and Tunisia). When related to fertility transition, one may want to argue that the evidence of possible sex preferences should be strengthened as family size decreases and third-birth progression increasingly becomes a deliberate choice. Thus, gender composition may play a large role within a low-fertility setting, such as contemporary Morocco. Yet, the preference towards a son may also be related to subcultures existing in the country: Morocco has predominantly Berber regions; it is not a homogeneously Arab nation. If the parental gender preferences are stronger among Arab populations than they are among the Berber population, as it has been suggested, then the ethnic and linguistic diversity of the country may weaken the degree of the son preference (Makhlouf Obermeyer and Cardenas 1997). A thorough examination of the differences between the Arab and Berber nation, however, would require a careful mapping of the settlement patterns of the two groups. The data, however, are not well suited to this purpose and such analysis is beyond the scope of the present study. 


\section{Preliminary findings and model specification}

The analysis is carried out using data from the most recent retrospective survey, l'Enquête sur la Population et la Santé Familiale (EPSF) 2003/04, conducted in Morocco as part of the Demographic and Health Surveys. It was designed to provide information on fertility levels and trends, infant and child mortality, family planning, and mother and child health of a nationally representative sample of the Moroccan population. The survey was fielded between October 2003 and February 2004. Face-toface interviews were carried out in 11,513 households and involved 16,798 women: all women aged 15 to 49 who visited the household in the night before the interview or who generally lived in the household were eligible to take part. A weighted, multistage, stratified cluster sampling approach was used in the selection of the sample.

A first glance at the progression to third birth in Morocco shows significant differentials in behavior according to some socio-demographic characteristics of women and their husbands, such as the educational level ${ }^{3}$, the childhood place of residence, and the sex composition of children born previously (Table 1).

Constant lower proportions of literate women, who are married to highly educated men and live in urban settings, who have experienced third birth five and ten years after second childbirth suggest that the more emancipated strata of the population postpones higher-order births. Thus, the preliminary outcomes highlight the complexity of the picture, revealing marked differences in the transition to third birth among the population subgroups. By contrast, balanced percentages of mothers who have experienced third childbirth five and ten years into the second birth, by the sex composition of the previous children, may suggest that there is an attenuated effect of this variable on reproductive behavior.

For the purpose of the analysis, basic socio-economic and demographic characteristics of women are investigated, using a piecewise constant intensity regression model on the probability of third childbirth. Because marriage is almost universal in Morocco and practically all births occur within marital unions, the analysis focuses on a sub-sample consisting of 5,645 currently married women (married only once) aged 15 to 49 who have already given birth to a second child at the time of interview (excluding cases with twins at second birth) and who were at risk of birth (starting eight months after second childbirth) ${ }^{4}$. A woman's third-birth risk is defined as the probability of experiencing third birth within the next month, given her individual and couple characteristics and given that she has delivered a second child by the

\footnotetext{
${ }^{3}$ The inclusion of the highest level of education ever reached is justified by the assumption that women and men have already concluded their education career at the time of second birth.

${ }^{4}$ The exposures have a median age of 27.1 years.
} 
Table 1: $\quad$ Transition from second to third birth, by selected sociodemographic characteristics in Morocco. Kaplan-Meier survival curve estimates.

\begin{tabular}{|c|c|c|c|c|}
\hline Socio-demographic variables & $\begin{array}{l}\text { Two-child } \\
\text { mothers who } \\
\text { experienced } \\
3^{\text {rd }} \text { childbirth } \\
5 \text { years after } \\
2^{\text {nd }} \text { birth }(\%)\end{array}$ & $\begin{array}{r}\text { Two-child } \\
\text { mothers who } \\
\text { experienced } \\
3^{\text {rd }} \text { childbirth } \\
10 \text { years after } \\
2^{\text {nd }} \text { birth }(\%)\end{array}$ & $\begin{array}{r}\text { Duration at } \\
\text { which } 25 \% \text { of } \\
\text { two-child } \\
\text { mothers } \\
\text { experienced } \\
3^{\text {rd }} \text { childbirth } \\
\text { (years) }\end{array}$ & $\begin{array}{r}\text { Duration at } \\
\text { which } 50 \% \text { of } \\
\text { two-child } \\
\text { mothers } \\
\text { experienced } \\
3^{\text {rd }} \text { childbirth } \\
\text { (years) }\end{array}$ \\
\hline \multicolumn{5}{|l|}{ Childhood place of residence } \\
\hline Rural & 80.6 & 93.0 & 1.8 & 2.7 \\
\hline Urban & 56.8 & 78.5 & 2.5 & 4.4 \\
\hline \multicolumn{5}{|l|}{ Woman's educational level } \\
\hline No education & 83.8 & 93.9 & 1.8 & 2.5 \\
\hline Primary & 64.7 & 87.1 & 2.2 & 3.8 \\
\hline Secondary and higher & 46.6 & 73.2 & 3.0 & 5.3 \\
\hline \multicolumn{5}{|l|}{ Husband's educational level } \\
\hline No education & 84.3 & 94.2 & 1.7 & 2.5 \\
\hline Primary & 74.7 & 90.8 & 2.0 & 3.1 \\
\hline Secondary and higher & 56.0 & 78.5 & 2.0 & 4.4 \\
\hline \multicolumn{5}{|l|}{$\begin{array}{l}\text { Sex composition of children born } \\
\text { previously }\end{array}$} \\
\hline Two girls & 76.6 & 91.3 & 1.9 & 2.9 \\
\hline One boy and a girl & 75.9 & 89.9 & 1.9 & 2.9 \\
\hline Two boys & 76.2 & 90.1 & 1.9 & 2.8 \\
\hline
\end{tabular}

Source: own calculations based on DHS 2003/04, Morocco.

beginning of the month. Risks are assumed to be constant within each time interval but may vary across such intervals. The process time (i.e. the baseline hazard) is the number of months elapsed since the birth of the second child. Next, a time-varying covariate aiming to capture the influence of changes in the socio-political environment on third-birth intensity is included. Three time periods are used for the categorization: until 1993, from 1994 to 1998, and from 1999 to the date of interview. This choice is motivated by the following reasons: (a) in 1993, the first royal reform of the Personal Status Code (Mudawwana, officially issued in 1957) was introduced, (b) in 1998, the "Plan national pour l'intégration de la femme au développement" was launched, and 
(c) in 1999, Muhammad VI, a liberal sovereign, was enthroned, with the declared intention to pursue democratic reforms, improve women's conditions, and assure human dignity ${ }^{5}$. These broad legal reforms are expected to have provided women more choice in matters of reproduction and contributed to compress family size. In fact, the strategies used by the state to consolidate its power have profound implications on the female status. In the countries of the Maghreb, for instance, the status of women reflects different processes of state formation and largely is a function of the relationship between the state and existing kinship structures (Charrad 1990).

Even though the Moroccan DHS includes a wide range of retrospective questions on women's reproductive lives, most background characteristics were obtained only at the time of the survey: migratory, employment, and contraceptive histories, for example, were not collected with individual life histories. It was impossible, then, to examine these variables in conjunction with preceding births and to regard them as explanatory variables due to the risks of performing an anticipatory analysis (Hoem 1996). Unfortunately, other important information on the regions of the respondent's childhood residence, their ethnicity, their mother-tongue as well as a detailed mapping of Berber and Arab regions must be neglected in the empirical analysis. This is because the Moroccan DHS data do not allow a thorough examination of these issues.

The following full multiplicative main-effects model has been estimated:

$$
h(k)=a_{t(k)} b_{l} c_{m} d_{n(k)} e_{o} f_{p} g_{r} h_{s}
$$

where $h(k)$ is the third-birth intensity, which depends on various factors, $a$ represents the basic time factor (the number of months elapsed since second childbirth), $b$ denotes the age at first marriage, $c$ represents the length of previous birth interval, $d$ is the calendar period, $e$ denotes the woman's childhood place of residence (where the woman in question lived most of her time until she reached age 12), $f$ indicates the woman's educational level, $g$ is the husband's educational level, and $h$ represents the sex composition of previous offspring. The variables are grouped into categorical levels, indexed by t, l, m, n, o, p, r, and s.

The sub-sample used in this analysis indicates that around $70 \%$ of the respondents and half of their husbands have no formal education, and this appears to be consistent with Moroccan schooling levels. With regard to the urban-rural distribution of the Moroccan mothers included in the analysis, about $66 \%$ lived in rural areas during their childhood, reflecting the low levels of past urbanization in the country. Half of the two-

${ }^{5}$ The official issue of the new Family Code on $9^{\text {th }}$ February 2004 has strongly been influenced by the direct involvement of Muhammad VI. 
child mothers married early, i.e. by the time they reached 19 years of age, and for nearly $64 \%$ of them the time interval between the first two births was not shorter than two years.

Information on the union histories of the survey respondents is unfortunately not available, thus only women living in intact first unions are included in the study; if union-disruption levels are of major importance in the country, this implies some dangers of anticipation for future behavior. In order to achieve an indication whether this issue represents a serious data problem, an appropriate description of all two-child Moroccan mothers by number of unions and marital status is included (Table 2). Among the 6,172 currently married women, the percentage of those married two or more times stands at 8.5 and this proportion rises to $9.6 \%$ among all ever-married women. Therefore, the data presented here seem to suggest that divorce is not particularly uncommon in Morocco; however, the issue is far from being of major importance, so that it may not cause too large problem in the empirical analysis.

To support this statement, the author refers to general macro data available on divorce in Morocco in addition to the DHS data; the proportions of divorced women aged 15 and over are derived from 1960, 1971, 1982, 1994, and 2004 census data (Table 3). The fraction of divorced women has constantly been weak and is even declining over time.

Table 2: Two-child mothers by number of unions and marital status, Morocco, 2003/04.

\begin{tabular}{lrrrrrr}
\hline \multirow{2}{*}{ Marital status } & \multicolumn{2}{c}{ One union } & \multicolumn{3}{c}{ More than one union } & \multicolumn{2}{c}{ Total } \\
\cline { 2 - 7 } & \multicolumn{1}{c}{ a.v. } & \multicolumn{1}{c}{$\%$} & a.v. & \multicolumn{1}{c}{$\%$} & a.v. & $\%$ \\
\hline Married & 5,645 & 91.5 & 527 & 8.5 & 6,172 & 100.0 \\
Widowed & 206 & 75.5 & 67 & 24.5 & 273 & 100.0 \\
Divorced & 96 & 70.6 & 40 & 29.4 & 136 & 100.0 \\
Not living together & 21 & 91.3 & 2 & 8.7 & 23 & 100.0 \\
Total & 5,968 & 90.4 & 636 & 9.6 & 6,604 & 100.0 \\
\hline
\end{tabular}

Source: own calculations based on DHS 2003/04, Morocco. 
Table 3: Female population aged 15 and over, by marital status (in \%), Morocco, each census: 1960-2004.

\begin{tabular}{lrrrrr}
\hline \multirow{2}{*}{ Marital status } & \multicolumn{5}{c}{ Year of census } \\
\cline { 2 - 6 } & 1960 & 1971 & 1982 & 1994 & 2004 \\
\hline Single & 7.3 & 15.6 & 25.6 & 31.9 & 34.0 \\
Married & 71.2 & 66.1 & 58.8 & 54.8 & 52.8 \\
Widowed & 15.8 & 14.1 & 11.7 & 10.0 & 10.1 \\
Divorced & 4.2 & 4.1 & 3.9 & 3.4 & 3.1 \\
Unknown & 1.5 & 0.0 & 0.0 & 0.0 & 0.0 \\
Total & 100.0 & 100.0 & 100.0 & 100.0 & 100.0 \\
\hline
\end{tabular}

Source: United Nations, 2000; for 2004, see www.clad.hcp.ma.

Yet, consistently with the findings of other scholars (Kishor and Neitzel 1996, Fargues 2003b, El-Saadani 2006), it seems that Morocco stands in sharp contrast with the Western world, as do many other Arab and Muslim countries. While in the Western countries socio-economic development ${ }^{6}$ is associated with rising divorce rates (although in most cases the rates have levelled off), in the Arab region it appears to be concurrently associated with declining rates.

\section{Results}

The model parameters, produced as maximum-likelihood estimates, are presented in the form of relative risks (Table 4). Delayed marriage is associated with lower third-birth intensity, although the decrease seems to be a marginal one. The model has also controlled for the length of the previous birth interval, which appears to be an important and significant covariate: short intervals between the first and the second child are associated with higher transition rates, while long intervals are associated with lower ones.

\footnotetext{
${ }^{6}$ Including urbanization, modernization and industrialization, spreading education, higher female labor-force participation, changes in the societal traditional norms and values driving the patterns of family formation and dynamics.
} 
Table 4: Relative risk (and level of significance) of giving third childbirth for two-child mothers, standardized by selected socio-demographic characteristics, Morocco, 2003/04.

\begin{tabular}{|c|c|c|}
\hline Variables & Relative risks & $p$-values \\
\hline \multicolumn{3}{|l|}{ Age at first marriage } \\
\hline$<20$ & 1 & \\
\hline $20-22$ & 0.96 & 0.332 \\
\hline $23-25$ & 0.88 & 0.013 \\
\hline$>25$ & 0.72 & 0.000 \\
\hline \multicolumn{3}{|c|}{ Length of previous birth interval } \\
\hline$<2$ years & 1 & \\
\hline$\geq 2$ years & 0.54 & 0.000 \\
\hline \multicolumn{3}{|l|}{ Calendar period } \\
\hline $1989-1993$ & 1 & \\
\hline 1994-1998 & 0.69 & 0.000 \\
\hline 1999-2003/04 & 0.54 & 0.000 \\
\hline \multicolumn{3}{|l|}{ Childhood place of residence } \\
\hline Rural & 1 & \\
\hline Urban & 0.77 & 0.000 \\
\hline \multicolumn{3}{|l|}{ Woman's educational level } \\
\hline No education & 1 & \\
\hline Primary & 0.85 & 0.002 \\
\hline Secondary and higher & 0.73 & 0.000 \\
\hline \multicolumn{3}{|l|}{ Husband's educational level } \\
\hline No education & 1 & \\
\hline Primary & 0.85 & 0.000 \\
\hline Secondary and higher & 0.75 & 0.000 \\
\hline \multicolumn{3}{|c|}{ Sex composition of children previously born } \\
\hline Two girls & 1.00 & \\
\hline One boy and a girl & 0.95 & 0.203 \\
\hline Two boys & 0.93 & 0.067 \\
\hline \multicolumn{3}{|l|}{ Duration since second birth ${ }^{a)}$} \\
\hline$<1.50$ year & 1 & \\
\hline $1.50-2.49$ years & 4.15 & 0.000 \\
\hline 2.50-3.99 years & 4.84 & 0.000 \\
\hline $4.00-5.99$ years & 4.93 & 0.000 \\
\hline $6.00-18.50$ years & 3.09 & 0.000 \\
\hline
\end{tabular}

Source: own calculations based on DHS 2003/04, Morocco.

Log-likelihood $=-5203.1899$.

a) The duration has been computed starting from eight months following second childbirth. 
The childhood place of residence is an important predictor of fertility change: as expected, those who grew up in a rural context are characterized by a higher transition rate from the second child to the third.

The educational composition of the population also appears to determine the course of fertility, at the net of the other observed variables. Greater female access to education and greater educational opportunities (although these are wider in urban areas) are significant determinants of the transition from second to third birth in Morocco: among the women who already have two children, those who have a lower level of education show a higher probability of bearing another child. Schooling seems to be an important agent of socialization as it plays a crucial role in shaping attitudes, opinions, and values. However, it is not only women's but also husbands' higher educational standards that significantly impact the propensity of third childbirth. The results in the model indicate that the risk of progressing to third parity decreases at a similar intensity both for better educated women and men - with primary schooling as well as with secondary education - compared to the least educated subgroups ${ }^{7}$. The Ushaped relationship between education and fertility documented in several developing countries does not seem to apply to Morocco; instead, it seems that fertility falls uniformly as the educational attainment of women and husbands rises ${ }^{8}$. Thus, the hypothesis stating that women's third birth propensity is differentiated by a plurality of socio-economic characteristics seems to be corroborated by empirical evidence.

As for the calendar period, the results show that the highest progression risk is in the first period and then the risk diminishes at each subsequent level. In the last period, the risk is lower by $46 \%$ than for the period up to 1993 . Finally, there seems to be a slight tendency towards a boy preference in the progression from second to third child, even if this tendency admittedly is not statistically significant ${ }^{9}$.

In order to catch the process of fertility decline over time by women's educational level, an interaction model was fitted. Its estimates are shown in Table 5. The results reveal that all segments of the population are rapidly changing their fertility behavior; third-birth appears to decline monotonically across all educational groups at a similar rate. Within the framework of ongoing modernization, even the most "laggard" group such as illiterate women - shows a decrease in third-birth intensity during the 1990s.

\footnotetext{
${ }^{7}$ A model including an interaction term between female and male educational levels was also fitted; the outcomes, however, showed no strong and meaningful effects among the categories considered.

${ }^{8}$ Note that men's educational level is a variable reflecting the perception of their wives, with information not directly requested of the husbands.

${ }^{9}$ The introduction of the interaction between the calendar period and the sex composition of the previous offspring did not produce significant results: an examination of the statistical tests suggested that there is no real interaction at all. The results also revealed that none of the differences within calendar periods were significant; therefore, they are not presented here.
} 
The lack of strong interaction between women's educational attainment and time period challenges some of the assumptions on how fertility changes when transition advances $^{10}$.

Table 5: Relative risk (and level of significance) of third childbirth for twochild mothers, by interaction between calendar period and woman's educational level, standardized by selected socio-demographic characteristics, Morocco, 2003/04.

\begin{tabular}{lccc}
\hline & \multicolumn{3}{c}{ Calendar period } \\
\cline { 2 - 4 } & $1989-1993$ & $1994-1998$ & $1999-2003 / 04$ \\
\hline Woman's educational level & 1 & $0.66(0.000)$ & $0.51(0.000)$ \\
$\quad$ No education & $0.79(0.002)$ & $0.60(0.000)$ & $0.47(0.000)$ \\
Primary & $0.58(0.000)$ & $0.54(0.000)$ & $0.42(0.000)$ \\
$\quad$ Secondary and higher & & & \\
\hline
\end{tabular}

Source: own calculations based on DHS 2003/04, Morocco.

The interaction is controlled for all the other factors considered in the model presented in Table $4 . \quad$ LR $=11.5234>\chi_{4}^{2}(0.95)$.

\section{Conclusions}

The process of fertility decline is now under way in all of the South and East Mediterranean countries, so that the present fertility level stands at about half of that of the Seventies. Widely available education and urbanization have influenced reproductive behavior and, despite the limited presence of females in the labor market, the irreversible fall in fertility is leading to considerable social transformations, such as the erosion of the patriarchal system and the promotion of women's empowerment.

This paper has focused on Morocco, a country that is experiencing multidimensional modernization and an important diffusion of smaller families. A description of the progression from second to third birth has been provided with empirical results illustrating the general dynamics at this very critical phase of family building during advanced fertility transition.

\footnotetext{
${ }^{10}$ The author also did not find (data not shown) significant interaction between woman's educational attainment and the sex composition of children previously born: none of the differences among the categories were substantially meaningful.
} 
The findings show that differences among social groups still persist in the country: women with a lower educational level and with a rural background display higher risks of third childbirth. Nevertheless, the paper has also demonstrated that the dynamic process of modernization in Morocco, directed at promoting women's empowerment, acts even on the fertility behavior of women who still have a low educational level. Third-birth fertility appears to decline monotonically for all educational groups. This suggests that the general fertility drop in Morocco is due to strong general period effects that affect all strata of the Moroccan population and various composition effects where increasingly large groups of the population join the socio-economic groups that have the lowest fertility. Therefore, should the ongoing trend towards higher female educational standards and towards the promotion of their social status continue in Morocco, we can expect a smaller number of large families in the near future. Women's position and emancipation are key concerns in implementing further fertility decline. A national challenge will be to narrow and eventually eliminate the persistent wide gaps among the subgroups of the population.

Moreover, the analysis shows no consistent or clear evidence of sex preference among Moroccan mothers in the progression to the third child. There seems to be a slight aversion towards having two girls, which may make sense as gender composition may be a strengthened factor in a low-fertility setting; however, this tendency admittedly is not statistically significant.

\section{Acknowledgements}

This project was carried out during my stay at the Max Planck Institute for Demographic Research as a fellow in the European Doctoral School of Demography. I am grateful to Jan M. Hoem for his useful teaching during the Winter-Semester 2005/06. The work of Yavuz (2005) constituted a reading inspiration. I would also like to thank Daniele Vignoli for the motivating exchange of opinions during the elaborations on the analysis. Paola Di Giulio and two anonymous reviewers are gratefully acknowledged for their insightful and helpful comments. Susann Backer is acknowledged for the valuable language editing of this paper. 


\section{References}

Ajbilou A. (1998). Analyse de la variabilité spatio-temporelle de la primo-nuptialité au Maghreb (1970-1980). Louvain-La-Neuve: Academia Bruylant.

Arnold F. (1992). "Sex Preference and Its Demographic and Health Implications". International Family Planning Perspectives, 18, 3: 93-101.

Azelmat M., Ayad M., Abdelmoneim A. (2005). Enquête sur la Population et la Santé Familiale (EPSF) 2003/04. Ministère de la Santé Publique (Maroc), Macro International Inc, Ligue des États Arabes.

Bakass F. (2003). Fécondité et santé reproductive au Maroc. Approche offre-demande de la dynamique de la pratique contraceptive. Louvain-La-Neuve: Academia Bruylant.

Bongaarts J. (2006). “The Causes of Stalling Fertility Transitions”. Studies in Family Planning, 37, 1: 1-16.

Cain M. (1984). Women's Status and Fertility in Developing Countries: Son Preference and Economic Security. World Bank Staff Working Papers, 682. Population and Development Series, 7. Washington, DC: The World Bank.

Cered (1997). Situation et perspectives démographiques du Maroc. Rabat: Royaume du Maroc, Premier Ministre, Ministère de la Prévision Économique et du Plan.

Cered (1998). Population et développement au Maroc. Rabat: Royaume du Maroc, Premier Ministre, Ministère de la Prévision Économique et du Plan.

Charrad M. (1990). State and gender in the Maghreb, Middle East Report March-April: 19-24.

Cochrane S. (1979). Fertility and Education: What Do We Really Know?. Baltimore: Johns Hopkins University Press.

Courbage Y. (1994a). "Évolution démographique et attitudes politiques en Syrie”. Population, 3: 725-749.

Courbage Y. (1994b). “L’imprévisible fécondité égyptienne”. Population, 1: 211-222.

Courbage Y. (1994c). Péninsule arabique: les surprises de la démographie, MaghrebMachrek, 144.

Courbage Y. (1995). Fertility transition in the Mashriq and Maghrib, in Makhlouf Obermeyer C. (ed.), "Family, gender and population in the Middle East”. Cairo: The American University in Cairo Press: 80-104. 
Courbage Y. (1999a). "Economic and Political Issues of Fertility Transition in the Arab World - Answers and Open Questions”. Population and Environment, 20, 4: 353-380.

Courbage Y. (1999b). Nouveaux horizons démographiques en Méditerranée, Travaux et Documents, 142. Paris: INED. Updated English version available at: www.ined.fr/englishversion/publications/collections/courbage/td142A.htm.

Courbage Y. (2001). Sur les pas de l'Europe du Sud: la fécondité au Maghreb. Available at: http://www.un.org/esa/population/publications/completingfertility /RevisedCourbagepaper.PDF.

DaVanzo J., Starbird H. (1991). "Correlates of short inter-birth intervals in peninsular Malaysia: Their pathway of influence through breastfeeding and contraceptive use”. Studies in Family Planning, 22, 4: 241-254.

Deane Abernethy V. (2002). Fertility decline; no mistery, Ethics in Science and Environmental Politics, available at: http://www.int-res.com/articles/ esep/2002/article1.pdf.

Di Comite L., Moretti E. (1999). Geopolitica del Mediterraneo. Roma: Carocci.

El-Saadani S.M. (2006). "Divorce in the Arab Region: Current Levels, Trends and Features”. Liverpool: European Population Conference, 21-25 June 2006.

Eltigani E.E. (2001). “Childbearing in Five Arab Countries”. Studies in Family Planning, 32, 1: 17-24.

Fargues Ph. (1988). “Baisse de la fécondité arabe”. Population, 43, 6: 975-1004.

Fargues Ph. (1995). Changing hierarchies of gender and generation in the Arab World, in Makhlouf Obermeyer C. (ed.), "Family, gender and population in the Middle East”, Cairo: The American University in Cairo Press: 80-104.

Fargues Ph. (2003a). "La femme dans les pays arabes: vers une remise en cause du système patriarcal”. Population et Sociétés, 387.

Fargues Ph. (2003b). Terminating Marriage, in Hopkins N.S. (ed.), "The New Arab Family”. Cairo Papers in Social Demography, 24. Cairo: The American University in Cairo Press: 80-104.

Héran F. (2004). “Cinq idées reçues sur l'immigration”. Population et Sociétés, 397.

Hoem J.M. (1996). "The harmfulness or harmlessness of using an anticipatory regressor: how dangerous is it to use education achieved as of 1990 in the 
analysis of divorce risks in earlier years?”. Yearbook of Population Research in Finland, 33.

Kishor S., Neitzel K. (1996). The Status of Women: Indicators for Twenty-Five Countries. DHS Comparative Studies, 21. Calverton, Maryland: Macro International Inc.

MakhLouf Obermeyer C. (1993). “Culture, Maternal Health Care, and Women's Status: A Comparison of Morocco and Tunisia”. Studies in Family Planning, 24, 6: 354365.

MakhLouf Obermeyer C. (1996). "Fertility norms and son preference in Morocco and Tunisia: does women's status matter?”. Journal of Biosocial Science, 28: 57-72.

MakhLouf Obermeyer C. (1999). Fairness and fertility: The meaning of son preference in Morocco, in Leete R. (ed.), "Dynamics of Values in Fertility Change". London: Oxford University Press: 275-292.

MakhLouf Obermeyer C., Cardenas R. (1997). "Son preference and Differential Treatment in Morocco and Tunisia”. Studies in Family Planning, 28, 3: 235-244.

Mason K. (1985). The Status of Women. New York: The Rockfeller Foundation.

Rashad H., Khadr Z. (2002). "Demographic Transition in Arab Countries: A New Perspective”. Journal of Population Research, 1: 83-101.

Repetto R. (1972). “Son Preference and Fertility Behavior in Developing Countries”. Studies in Family Planning, 3, 4: 70-76.

Salvini S. (1994). Trasformazioni economiche, pressioni demografiche e cambiamenti della società patriarcale negli stati che si affacciano sull'altra sponda del Mediterraneo. Politica internazionale, 2.

Tabutin D., Schoumaker B. (2005). "La démographie du monde arabe et du MoyenOrient des années 1950 aux années 2000. Synthèse des changements et bilan Statistique”, Population, 60, 5-6: 611-724.

United Nations (2000). Demographic Yearbook, Historical Supplement 1948-1997. New York, Geneva: United Nations Publications.

Yaakoubd A.I (1997). "La transition de la fécondité au Maroc: faits et facteurs”. Genus, 53, 1-2: 189-202.

Yavuz S. (2005). "Fertility transition and progression to third birth in Turkey". Max Planck Institute for Demographic Research Working Paper, WP 2005-028. http://www.demogr.mpg.de/papers/working/wp-2005-028.pdf. Since published 
D'Addato: Progression to third birth in Morocco in the context of fertility transition

in Demographic Research, Volume 15, http://www.demographicresearch.org/volumes/vol15/17/. 